\title{
A TOOLBOX FOR MAPPING AND MANAGING NEW INTERESTS OVER LAND
}

\section{R. Bennett, J. Wallace and I. P. Williamson}

Department of Geomatics, The University of Melbourne, Victoria 3010 Australia

\section{ABSTRACT}

The drive for sustainable development has led governments to create new interests over land. The role of cadastral and registration systems in the mapping and management of these new interests is unclear. Whilst these systems have always played an important role in the administration of land parcels and ownership, the new land interests are increasingly being mapped and managed elsewhere. As a result administrative inefficiencies and transaction complexities are growing. Existing cadastral and registration systems have the capacity to improve the situation; however, a guiding framework for their inclusion is needed. This paper introduces a framework of principles that articulate the roles of cadastres and registration systems in the management of new land interests. Importantly the framework is holistic and reflects other components essential to good land administration. These include the roles of land policy, legislation, flexible tenures, institutions, spatial data infrastructures and capacity building. The principles will systematize the management of land interests across different jurisdictions.

KEYWORDS: Cadastral Surveying. Land Administration. Land Interests. Property Rights.

\section{INTRODUCTION}

The statute books of many countries are bursting at the seams. Governments at local, national and international levels all contribute to this body of regulation. A study completed in 2006 found that in the previous decade, the Australian government created more legislation than generated in its first ninety years [1]. Similar statistics can be found at the state and local levels in Australia [2]. Western European countries have experienced similar trends $[3][4][5]$. Land regulation in particular has received a great deal of attention: climate change, soil erosion, illegal land clearing, salinity, drought, livestock disease, mining booms, housing booms, global agriculture, urban sprawl, social equity, heritage protection and native title have all driven the explosion in legislated land interests (also known as property rights, restrictions and responsibilities (RRRs))

While controls are often contentious, they tend to be less problematic if they're designed and administered in fair and efficient ways. However, these management qualities have often been overlooked in the recent regulatory rush. For example, a delay of two years for a decision on a mining license can hardly be considered efficient. Fining a land owner for illegal vegetation clearing where only minimal spatial information and education are provided appears unjust [6]. Problems like these arise because many of the new interests are created and managed in isolation from the pre-existing cadastral and land registration systems. These systems evolved over hundreds of years, are well understood by citizens and have traditionally administered all significant land interests. The recent regulatory push instead relies on multiple systems, undermining the concept of authoritative land information, creating administrative inefficiencies, complicating land transactions and resulting in administrative voids within government.

These problems have been recognized at various levels. The surveying and land administration professions have been instrumental in creating awareness. At the international level the International Federation of Surveyors (FIG) published Cadastre 
2014 in 1998 [7]. This visionary document recommended that future cadastral systems record and show all interests in land. Western European countries are leading implementation of the vision. The Netherlands recently passed the "Law on Registration of Public Encumbrances 2005". This initiative was driven by Netherlands Kadastre and obliges all municipalities to establish and maintain a publicly available register of all land interests imposed on real estate [3][4]. Switzerland is also in the process of passing a similar law [5]. Swisstopo, the federal agency administering the cadastre, has been heavily engaged in the process. The administrative practicalities of these new laws are still being resolved; however, imposition of legislative requirements on government appears to be an important component of any solution.

Australia is also taking action. In 2004, ANZLIC, the Spatial Information Council of Australia and New Zealand and the peak body dealing with spatial and land information issues, released a communiqué outlining the need for better management of all rights, restrictions and responsibilities on land [8]. Most practical developments are occurring at the state level. In 2005, at the Expert Group Meeting on Sustainability and Land Administration held at The University of Melbourne, all of the states represented were undertaking projects to improve land information management [9]. Technology was a major focus, in particular the utilization of newly available spatial technologies and concepts including spatial data infrastructures (SDI), spatial databases and web mapping services. These tools allow for integration of complex legislative and administrative systems without the need to reorganize government institutions. They also assist distribution of land information to citizens. Western Australia's Shared Land Information Platform (SLIP) and accompanying Register of Interests (ROI) web application provide best practice examples of the tools in action [10].

These innovations demonstrate that a range of different tools can be used to address the problem. However, focusing solely on technology, legislation or organizational structures will result only in short term success: no single tool can provide a sustained long-term solution. For example, web mapping services do not stop governments from writing bad legislation. Therefore, to be successful, projects aimed at improving land administration and management must be holistic in nature [11]. The Land Administration Toolbox, used in surveying and land titling projects, is an example of a holistic approach. All land administrative systems need to incorporate its eight tools in order to be sustained [11][12]. These include land policy aspects, legal components, tenure organization, institutional arrangements, cadastral surveying methods, technological components, SDI initiatives and human capacity building aspects. For each tool a range of options are available, the selection of which is based on a country's context.

The toolbox provides a framework for understanding, building and comparing different land administration systems; however, its focus is on the management of ownership rights. It does not necessarily cover all the new interests, restrictions and responsibilities that have been placed on land. Many of the interests being created are very different to ownership rights and may need to be managed in different ways [13]. Therefore this paper proposes to extend the Land Administration Toolbox to include tools appropriate for the creation and administration of all land rights, restrictions and responsibilities. This paper introduces the updated toolbox by outlining the methodology used to develop it and then by providing an overview of each of tool and its importance.

\section{DEVELOPING THE TOOLBOX}

The toolbox was developed by the Centre for SDI and Land Administration at the University of Melbourne. A mix of qualitative and quantitative analysis was used to 
develop and validate the framework [14]. First, three case studies were undertaken at each level of government in Australia. The jurisdictions of the Australian government, Victoria at the state level and Moreland City Council were chosen. For each jurisdiction every land interest created in legislation was identified and a number of attributes recorded in a database. The attributes closely followed those identified in the land administration toolbox and included policy, legislative, institutional, ICT, spatial, access and registration aspects. This phase facilitated the creation of a classification framework of different land interests [2]. It also allowed for weaknesses of the new land interest administrative systems to be identified when compared against the traditional land administration toolbox. A preliminary set of additional tools were developed at the end of this phase.

The second phase involved a review of international developments. A number of leading countries from Europe and North America were chosen. This international study facilitated analysis of the types of tools and approaches being used to address the problem in countries with highly developed land administration systems and land markets. An appreciation of the utility and limitations of each tool was formed. This phase also acted as a check to ensure that the new principles generated from the Australian case studies were internationally applicable.

The final phase involved investigating the information needs of property owners. A range of different property types were investigated. These included an agricultural property, two urban residential properties and a coastal property. The results from these investigations were used to further validate, refine and consolidate the set of administrative tools.

\section{RESULTS AND DISCUSSION}

Analysis of all results arising from this research is outside the scope of this paper. Instead, a summary of the key principles and additional tools identified throughout the research is provided.

\section{The Land Administration Toolbox RRR Edition}

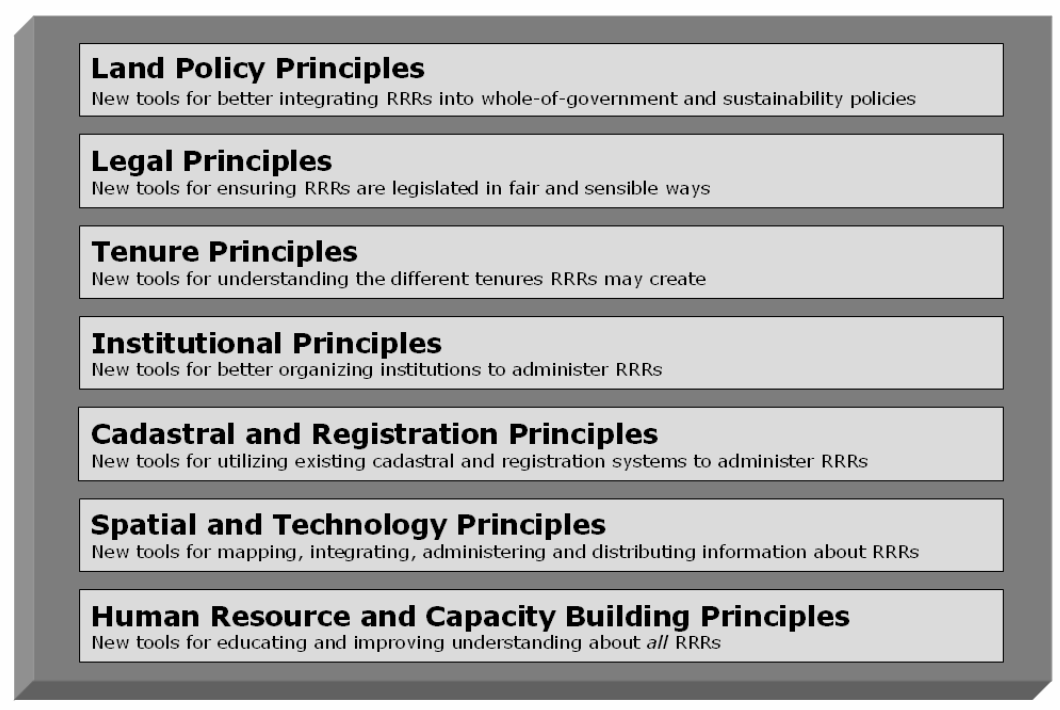

Fig. 1. Updated Land Administration Toolbox components 
The new tools are organized into the categories similar to those in Williamson's land administration toolbox [11]. However, a number of alterations are made (Figure 1). Legal and Human resource capacity building principles are included. These tools did not appear in the original toolbox, however, they were added in later versions [12] and therefore appear here also. Cadastral principles now include registration principles. A wide range of registration options are available for dealing with land interests that do not equate to full ownership; these are included in this component. SDI and technology principles are merged, reflecting the convergence of spatial technologies and ICT that occurred after the original toolbox was developed.

\section{Land policy principles: sustainability is essential}

Land policies underpin all other land administration activities. They drive legislative reform which in turn results in institutional and administrative reform [11]. Williamson's original tool suggests a policy framework could recognize the growing complexity of rights, restrictions and responsibilities relating to land and the consequent demands on land administration infrastructures. This inclusivity is now non-negotiable, as are the other new principles in Table 1.

\section{Table 1. Tool \#1 New land policy principles}

\section{Sustainable development theory must drive land policy creation}

The large majority of new land interests are created in response to environmental decline and need regional, not parcel based, approaches. Having holistic land policies based around sustainability will result in more efficient legislative design and administration.

Land policies must reflect the whole-of-government nature of land administration It has been found that $60-70 \%$ of government legislation relates to land [6]. This means a large portion of government agencies collect, provide or use land and spatial information. Land policies must promote government collaboration.

\section{Local level empowerment in land policy design is essential}

Globalization is driving the resurgence of local government, as is the principle of subsidiarity (placing management responsibility as near as possible to the problem that is at the lowest hierarchical level) that drives much of European Union organization. While central governments will still set policy frameworks, local governance will provide the leadership, the networks, the knowledge and the commitment [15]. Local governments need to be given an active role in land policy creation and implementation.

\section{Integration of land policies across and between levels of government is critical}

Environmental issues do not respect administrative boundaries. Land policies must be developed through coordination of different levels of government. Collaboration and cooperation must be embedded into land policy implementations.

\section{Land policies must include appropriate incentive schemes}

When designing land policies the right mix of economic, social and moral incentives for citizens needs to be determined. Examples include market based interests (MBIs), compensation arrangements, land care agreements, rewards schemes or penalties.

The Australian experience illustrates the need for organized and coordinated policies when dealing with interests over land. At the national level, Australia lacks an 
overarching land policy. The constitution makes no mention of land, except to require just compensation for its taking by government. No Australian state has an overarching land policy. This lack of policy organization is one contributor to the masses of legislation created to counter environmental problems. A framework of land policies based around the principles of sustainable development would improve this situation. The policy framework could be organized through national, state and local collaboration. Land policies with a whole-of-government approach would go some way to decreasing the amount of administrative overlap between national and state levels and within the state level.

\section{Legal principles: keep it simple}

Legislative principles relate to the design of statutory rules and regulations. Williamson's original toolbox did not include legal principles; these were added in later versions [11],[12]. The central idea is that creation of new legislation must be driven solely by sound land policies. Other recommendations include minimizing the amount of legislation, integrating land administration legislation through the national code and the use of sunset clauses. Table 2 introduces a number of new legal principles.

\section{Table 2. Tool \#2 New legal principles}

Government accountability must be embedded into legislation.

Governments creating land interests via legislation must make information about the interests publicly available. Lack of public information has been a major problem for private owners; legislating publication requirements will improve the situation.

\section{Spatial extent, duration and people impacted must be defined in legislation}

These three attributes of land interests have been poorly defined in legislation in the past [6]. The ability of governments to organize and integrate land information will be greatly improved if these attributes are defined in a uniform fashion and stored in authentic registers.

\section{Sunset clauses on all legislation creating land interests}

Lack of foresight by governments has resulted in land interests remaining applicable long after they were intended [2]. By ensuring all legislation has a review date or sunset clause these occurrences can be mitigated.

\section{Legislation should be drafted in a 'performance based' style}

Statutes that are written in formalistic proscriptive or descriptive styles are long and detailed. They demand more administration and often become out dated when new technologies emerge. Performance based legislation reduces complexity in administration and is more flexible in the long term.

\section{Trouble cases must not be used to develop reactionary legislation}

Legislation drafted in response to a widely publicized problem or dispute often creates more problems than it solves. Creation of land legislation must be driven solely by sound land policies.

The Netherlands are already actively implementing a number of these principles. Parliament passed laws requiring government agencies to publish land interest information [3][4]. Unlike privately held land interests that gain greater protection if recorded in a public register, public bodies have very little incentive to register their interests in a public record. This is because legislation often confers overriding powers 
on public agencies and secures their interests against all or most competitors. The new legislation provides an incentive for government bodies to publish their land information where one did not previously exist.

\section{Tenure principles: several types with several administrative responses}

If individuals have tenure over land, they have the right to undertake certain activities on that land [16]. The number and sort of activities that can be undertaken are determined by the type of tenure held. Williamson's tenure principles suggested that within any jurisdiction a wide range of tenures may exist, each potentially requiring a different administrative response [11]. Table 3 introduces a number of new principles relating to tenure.

\section{Table 3. Tool \#3 New tenure principles}

New land interests will impact on ownership

Every time a government creates a new interest over land, no matter how insignificant it might seem, a new tenure is also created [2]. New tenures can weaken private ownership, a foundation pillar of modern economies. The creation of new interests requires careful consideration of the potential impact on ownership and land markets.

\section{New land interests can be categorized into three main tenure typologies}

From a tenure perspective three main categories emerged from legislative analysis:

1. Private or Tradable: interests that involve private parties and that may be tradable between private parties e.g. land parcels, water, carbon credits and timber licences.

2. Government Management: interests that allow government agents to use or transform the land.

3. Government Access: interests that allow governments to enter land.

\section{Not all land tenures belong in the registry}

Different types of land interests require different administrative responses [6].

Government security is not necessary for all land interests. Only private or tradable interests with an economic, social and environmental value should be included within the registry. Traditionally, title and deeds registries focused on those interests with economic significance. Examples include freehold, leasehold licenses, mortgages and rent charges. Some also include interests such as easements and covenants that assist private planning systems. This should continue to be the main role of the registry; its integrity underpins modern economies. However, some new interests created for environmental or social purposes, such as water interests, biota interests and tradable carbon interests also require security. These are generally private, tradable and economically valuable: ideal for management within a registry. Other less valuable interests, such government access and management interests do not require the security of a registry, information relating to them simply needs to be made available. These interests can be managed elsewhere and integrated using technology.

The Australian State of Victoria provides a good illustration of the value of these principles. Some land administration literature suggested the use of Torrens style registries to administer all land interests. In Victoria this would mean placing the administration of the 620 Acts which create land interests (more than half the statutes in the state), under the partial control of the registry [6]. Clearly this would be unworkable and another solution is required. 
The registry is a useful tool for managing specific kinds of interests. These interests tend to be private in nature and therefore require security from government. If a condition is placed on the registry that only private or tradable interests are registered, fewer than 100 of the 620 Acts would involve the registry, an administratively feasible goal. The remaining Acts involve government held interests such as access rights for agents of the state (e.g. cadastral surveyors). These usually require minimal administration and could be managed elsewhere. Integration of the registry information and other land information could then be achieved using new technological solutions for information provision [2].

\section{Institutional principles: shared responsibilities but centralized leadership}

Williamson's original institutional principles dealt with defining government structures such as ministerial responsibilities, departmental configurations and decentralization [11]. The principles also included private sector relationships and the operation of professional organizations. With respect to managing new land interests the principles in Table 4 are also necessary.

\section{Table 4. Tool \#4 New institutional principles}

\section{Structure: government remains decentralized}

Administration of land interests is spread across countless government departments and agencies. It is too costly and impractical to move all land interest information into a single agency. Existing government structures should remain: technology can assist integration of information.

Custodianship: control of information remains decentralized with government agencies Ownership of land information should remain with the primarily responsible government agencies. These organizations have the most intimate understanding of the information they collect. Universal distribution and information sharing agreements are required.

\section{Leadership: a single information coordination body is required}

A single coordination body, with statutory powers, should be responsible for driving and organising the integration of government and industry land information sets. Powers of this body need to be legislated otherwise integration may only occur on a case by case basis.

\section{Processes: government should be organized around land activities not institutions}

Technology can assist in overcoming historic communication problems across government (also known as the 'silo' problem). The core land processes undertaken by citizens (e.g. buying and owning a house) should be used to organize and integrate institutions and their information.

An illustration of well designed institutions can be found in the state of Western Australia. The state is a front runner in land information management. This success can largely be attributed to an integrated management plan, and a long established collaboration path through WALIS, Western Australia's Land Information System, a 25 year old network of government, industry and community bodies [17]. WALIS set up foundations for co-ordination of the State's geographic information, and facilitated policies and standards that ensured the effective management of vast information sets [18]. This history helped facilitate a holistic approach to land management in the state. 
The Department of Land Administration was transformed into Landgate, a department of land information. These changes led to the development of SLIP and subsequent integration of government and industry land information sets.

Cadastral and registration principles: selective application is important

Williamson lists many cadastral tools and concepts [11]. Table 5 provides a number of additional tools for managing new lands interests.

Table 5. Tool \#5 New cadastral and registration principles

Different land interests should be spatially mapped in different ways

The cadastral concept [19] demands that ownership interests be mapped spatially.

Analysis shows that this may not always be necessary for new land interests:

1. Private or Tradable: Must be spatially defined and available to public where possible.

2. Government Management: Must be spatially defined and available to public where possible.

3. Government Access: Do not necessarily require spatial identification.

\section{Different land interests should be registered in different ways}

Analysis suggested the tenure categories should be administered in the following way:

1. Private or Tradable: Torrens or deed registries should administer these

interests. Interests not requiring the security of a guaranteed register do not need to be included.

2. Government Management: The responsible government agency should record these interests. They should be linked to the registry through the SDI.

3. Government Access: These interests tend to require minimal administration and should be recorded by the responsible government agency.

Parcels provide predominant method of organizing land interests, but, non-parcel land interests are increasing in number

Governments are increasingly creating land interests that are non parcel is nature [2]. These interests may be spatially defined as polygons, networks or points. Cadastres must incorporate these new layers of spatial objects [7].

Non-parcel land interests will have virtual boundaries rather than physical monuments Cadastral parcels are demarcated in the physical world using survey pegs or other monuments. The advent of cheap GPS available to citizens reduces the need for new non-parcel land interests to rely on monumentation.

An example of the need to map and record interests in different ways can be found in Victoria. Recently a number of marine sanctuaries were created along Victoria's coastal waters [20]. These interests create management, withdrawal and access controls on vessels and people passing through the areas affected. The interests are not physically demarcated and GPS navigation systems must be used to assess boundary locations. The interests are spatially mapped and managed by Parks Victoria, the responsible government agency, in accordance with the above principles.

\section{Spatial and ICT principles: enabling new solutions}

While recognizing the importance of spatial technologies and ICT, Williamson also warned that focusing solely on technology often results in project failure [11]. Recognizing this, Table 6 introduces a number of new spatial and ICT tools. 
Table 6. Tool \#6 New spatial and ICT principles

Information: spatial extents, duration and people impacted must be recorded Location, time and people attributes should be defined and recorded in uniform fashion by government agencies. This will enable better ordering, integration and searching of land interest information.

Access: land interest information and transactions should be online and affordable Limited land transactions are available to citizens online. Many transactions are still paper based: only printable forms are provided online. Governments should strive to include the processes of creation, alteration and removal online.

\section{Infrastructure: SDI overcomes the need to reorganize government}

SDI removes the need to reengineer governments. Standard infrastructure platforms enable the integration of government information.

Interface: web services need to be designed around land activities not datasets Existing government web sites tend to allow citizens to view different land datasets, however, sites should be designed around core activities and transactions.

\section{Standards: uniform spatial identifiers and units need to be developed}

In the past different agencies used different spatial identifiers. Integration and efficiency demands that uniform units and identifiers be adopted.

Human resource development and capacity building principles: spatially skilled workforces are essential

To ensure the long term sustainability of any land administrative reform ongoing education of people in both public and private sectors must be implemented [11]. Limited understandings of spatial information technologies will continue to hamper efforts to reform land administrative systems unless awareness of spatial technologies is improved [21]. Table 7 introduces two new principles.

Table 7. Tool \#7 New HR and capacity building principles

Basic spatial education across governments and community

Government departments are experts in understanding the land interests they administer, however, use and understanding of basic spatial technologies is very limited. It is recommended that basic skill upgrading in the use of GIS and spatial information be undertaken across government agencies.

\section{Social learning and information provision rather than regulation}

The need for copious amounts of regulation can be decreased by making use of social education and information provision [22]. For example, if a property developer knows which land is contaminated there is no need to draft a law penalizing people for building on contaminated land, it simply wouldn't happen.

\section{CONCLUSION}

Iterative modification of cadastral and registrations systems will improve the management of all interests in land. Important environmental and economic problems will not be overcome if the current approach of ad-hoc legislative design and disparate administration systems continues. The updated Land Administration Toolbox provides 
a guiding framework for governments attempting to achieve integrated management. The toolbox is an evolving concept: new tools will continue to be added as innovative technologies and administrative best practices emerge. Funding principles, partnership building principles and the need to promote under utilized spatial technologies within government and in the private sector are areas requiring more attention.

\section{ACKNOWLEDGEMENTS}

We acknowledge the assistance of colleagues in the Centre for SDI and Land Administration, Department of Geomatics, University of Melbourne in the preparation of the article. We also acknowledge the Department of Sustainability and Environment, in Victorian Government for their support. We also thank Public Sector Mapping Agency (PSMA) of Australia, The State Government of New South Wales (NSW), The Government of Western Australia (WA) and Moreland City Council for their guidance and assistance with data collection.

\section{References}

1. Australian Government Regulation Taskforce, 2006. Rethinking Regulation: Report of the Taskforce on Reducing Regulatory Burdens on Business, Report to the Prime Minister and the treasurer. Australian Government, Canberra, Australia, January. http://www.regulationtaskforce.gov.au/ [accessed 13 June 2006].

2. Bennett, R., Wallace, J., Williamson, I.P., 2006. Organising land information for sustainable land administration. Journal of Land Use Policy. **accepted for publication April 2007.

3. Van der Molen, P., 2005. Incorporating Sustainable Development Objectives into ICT enabled Land Administration Systems in the Netherlands. Proc. Expert Group Meeting on Sustainability and Land Administration. Melbourne, Australia, November 9-11. 83-96.

4. Zevenbergen, J. and De Jong, J., 2002. Public Law Information Regarding Land: Dutch proposal for registration, Proc. FIG XXII International Congress, Washington, D.C., USA, April 19-26.

5. Miserez, J. 2006, Registration of Public Land Rights and Restrictions in a Land Administration System. Proc. XXIII International FIG Congress, Munich, Germany, October 8-13.

6. Bennett, R., Wallace, J., Williamson, I.P., 2006. Managing rights, restrictions and responsibilities affecting land. Proc. $5^{\text {th }}$ Trans-Tasman Conference, Cairns, Australia, 19-23 September.

http://www.geom.unimelb.edu.au/research/SDI_research/RRR/Cairns\%20\%20PAPER\%200007\%20Bennett\%20REVISED.pdf [accessed 29 November 2006].

7. Kaufmann, J., and Steudler, D., 1998, Cadastre 2014: A vision for a future cadastral system, Working Group 1 of FIG Commission 7, Switzerland

8. ANZLIC, 2004, Communique from the National Summit on Improving the Administration of Land \& Property Rights \& Restrictions, 16 November 2004, Brisbane.

http://www.anzlic.org.au/events_landsummit_Nov04_communique.html [accessed May 29 2007].

9. Williamson, I.P., Enemark, S. and Wallace, J. (Ed.)., 2005. Sustainability and Land Administration Systems, Proceedings of the Expert Group Meeting, Melbourne, Australia, 9-11 November 2005. 
10. Searle, G., and Britton, D., 2005. The Western Australian Shared Land Information Platform and Modern Land Information Systems, Proc. Expert Group Meeting on Sustainability and Land Administration, Melbourne, Australia, November 9-11, 117-132.

http://www.fig.net/pub/fig2006/papers/ts49/ts49_02_miserez_0321.pdf [accessed 29 November 2006].

11. Williamson, I.P. 2001. Land Administration "Best Practice" providing the infrastructure for land policy implementation. Journal of Land Use Policy, 18.

12. Williamson, I.P. 2004. Land Administration 'best practice' and the 'toolbox' concept, Lecture 11 - 451-418/607 Land Administration, 1 April. http://www.geom.unimelb.edu.au/subjects/451/418/418_2004/table.htm [accessed: 29 November 2006].

13. Bennett, R., 2006. Reshaping the management of property rights, restrictions and responsibilities. XXIII International FIG Congress, Munich, Germany, October $5-13$.

http://www.fig.net/pub/fig2006/papers/ts49/ts49_01_bennett_0256.pdf [accessed 29 November 2006].

14. Evans, D., and Gruba, P., 2002. How to write a better thesis. Melbourne Univeristy Press, Melbourne, Australia.

15. Mckinlay, P. 2005. Future of Local Government Summit: A New Zealand Perspective, Proc. The Futrure of Local Government Summit, Melbourne Convention Centre, June 7-8. http://www.mav.asn.au/folg2005 [accessed 29 November 2006].

16. Prosterman, R., and Hanstad, T., 1999. Legal Impediments to Effective Rural Land Relations in Eastern Europe and Central Asia: A Comparative Perspective, World Bank Technical Paper No 436, Europe and Central Asia Environmentally and Socially Sustainable Rural Development Series, Washington.

17. Warnest, M., 2005. 2005. A Collaboration Model for National Spatial Data Infrastructure in Federated Countries. $\mathrm{PhD}$ Thesis. The University of Melbourne.

18. WALIS. 2006. About WALIS. Western Australia's Land Information System. Western Australian Land Information System, Western Australia. http://www.walis.wa.gov.au/about_WALIS/ [accessed 01 December 2006].

19. FIG. 1996. FIG Statement on the Cadastre. http://www.fig7.org.uk/publications/cadastre/statement_on_cadastre.html [accessed 01 December 2006].

20. National Parks Act 1975 (Vic), Section 17D

21. Clausen, C., Rajabifard, A., Enemark, S. and Williamson, I., 2006. Awareness as a foundation for developing effective spatial data infrastructures. Proc. Shaping the change : XXIII International FIG Congress. International FIG Congress, No. XXIII, München, Germany, October 8-13.

22. The SLIM Project, 2004, Social Learning as a Policy Approach for Sustainable Use of Water. A field tested-framework for observing, reflecting and enabling. SLIM (Learning for the Integrated Management of Sustainable Use of Water at Catchment Scale), Framework, European Union. http://slim.open.ac.uk [accessed 29 May 2007]. 


\section{University Library}

\section{- M M I E R R A A gateway to Melbourne's research publications}

Minerva Access is the Institutional Repository of The University of Melbourne

Author/s:

BENNETT, ROHAN;WALLACE, JUDE;Williamson, Ian Philip

Title:

A toolbox for mapping and managing new interests over land

Date:

2008

Citation:

Bennett, R., Wallace, J., \& Williamson, I. P. (2008). A toolbox for mapping and managing new interests over land. Survey Review, 40(307), 43-53.

Publication Status:

Published

Persistent Link:

http://hdl.handle.net/11343/26681 